\title{
Study of Creative Industry Development Based on Pekalongan Batik Culture
}

\author{
Danarti Hariani ${ }^{1}$, Eliza $^{2}$, D Pratama $^{3}$ \\ Universitas Mohammad Husni Thamrin, Indonesia ${ }^{1}$ \\ Sekolah Tinggi Perpajakan Indonesia, Indonesia ${ }^{2}$ \\ Universitas Indraprasta PGRI, Indonesia ${ }^{3}$ \\ $\left\{\right.$ danarti@thamrin.ac.id $\left.{ }^{1}\right\}$
}

\begin{abstract}
Culture is a noble conception that is able to offer and attract interest and has been passed down from generation to generation in the community in a community or group. Cultural construction encompasses the system of ideas in the human mind as intellectual and arithmetic statements, so that it becomes a means of work, taste, and creativity, including things that are real, such as patterns of behavior, language, life tools, technology, social structures, beliefs, arts, law, morals that figure the characteristics and characteristics of society. Batik is a cultural entity because it shows the characteristics of Indonesian culture and is a typical Indonesian textile. Batik is an Indonesian textile that is in great demand and loved by the international community. This is a prospect for creative industry players, especially the batik industry, to explore and allow Indonesian batik culture in order to gain economic potential and strengthen the positioning of Indonesian batik internationally. Pekalongan City has the name branding namely World city of Batik and makes the only city chosen by UNESCO in the category of craft and folk art to make Pekalongn city focus on developing its creative economy, especially the batik industry in order to improve the competitiveness of Pekalongan city and advance the economy Pekalongan city community. This paper tries to identify the potential of creative industries based on Pekalongan batik and analyzes the development of creative industries based on Pekalongan batik in order to maintain the image of Pekalongan Batik as a result of creative work based on culture in the eyes of the world. This paper was prepared using a qualitative descriptive approach that tried to illustrate the economic potential of the creative industries based on Pekalongan batik and the efforts of its development.
\end{abstract}

Keywords: Culture-Based Creative Industries, Pekalongan Batik

\section{Introduction}

Batik is an Indonesian cultural work that has developed and been preserved for generations, nowadays batik has gained international recognition. Currently, batik has experienced rapid development. This is because it is supported by increasing consumer demand. With the variation of batik motifs that come from the modification of modern motifs that are combined 
with traditional motifs accelerate the harmonization of batik among the public. Batik is now a mass industrial commodity.

Pekalongan Batik that grows and develops is one of the characteristics of superior products that have been known and is a noble cultural heritage. As Y's art product and the most valuable cultural heritage, Pekalongan batik has developed to meet fashion needs. Pekalongan City is one of the cities in Central Java which has long been known as the batik city. With the slogan of the World city of Batik, Pekalongan city is one of the culture-based industries that has become batik as the main economic commodity in Pekalongan. The prospect of Pekalongan Batik industry is very promising compared to other regions. Based on data from the Pekalongan city government it is known that there are about 1,081 units spread across four sub-districts, namely West Pekalongan, East Pekalongan, North Pekalongan and South Pekalongan with employment of 12,937 people. The export value of Pekalongan batik products in 2017 reached USD 427 thousand. (Department of Industry and Workforce of Pekalongan, 2017 [1]

Batik MSMEs in Indonesia are obliged to have product excellence and the uniqueness of sustainable products to survive in competition. The batik industry players must be able to face global challenges, such as increasing product and service innovation, developing human resources and technology and expanding marketing areas [2] for batik industry players to continue to exist in the world of batik industry. Skills, innovation, and creativity of human resources are needed in the creation of a creative industry that brings positive results to increased product sales as well as increased visitors to batik tourism destinations, especially in Pekalongan. The batik development industry in Pekalongan must also be cultivated by the local government and the batik industry players through branding creation and the holding of batik events locally, nationally and internationally.

\section{Method}

This study uses a qualitative descriptive method that aims to get a complex picture, get detailed information and reports from respondents. The descriptive analysis in this study was conducted to get an overview of the conditions and potential of the creative industries of Pekalongan batik in fact. In addition, a comparison between the results of the related research and the correlation between the results of the research and the relevant theory or concept was also carried out. Focus on analyzing the development of Pekalongan batik creative industries based on the identification of strengths, weaknesses, opportunities, and threats of the Pekalongan batik industry. Based on the SWOT analyst, the development of the Pekalongan Batik Creative Industry can be obtained by current conditions so that it is more implementable.

\section{Result and discussion}

The results showed that the development of a creative industry based on Pekalongan Batik culture has great potential because it is supported by abundant cultural wealth, although in its development because Pekalongan City has a creative industry that has been able to promote the image of the city the creative industry is batik industry, through batik crafts, the Pekalongan has been determined to be a creative city of the world facing a number of obstacles such as: availability of productive, innovative and creative resources, especially human resources which have little mastery in good batik techniques, high production costs, unavailability of $\mathrm{R} \& \mathrm{D}$ institutions that help innovation so batik designs and products tend to 
be monotonous and less innovative. This is in line with Nurainun, Heriyana and Rasyimah stating that the competitiveness of the Indonesian batik industry faces obstacles namely high production costs, regulations made by the government have not touched directly to craftsmen, fewer human resources who master good batik techniques, the difficulty get raw material and unfavorable security [3]. Although his research is generally for Indonesian Batik the aforementioned constraints that occur in Pekalongan batik only on the availability of resources and high production costs, while for regulation, the availability of raw materials and safety factors for the Pekalongan batik industry is not a significant obstacle. The challenge of the Pekalongan batik industry today is also related to competition and globalization is a matter of patents that have not yet become a necessity for Pekalongan batik artisans so that their patterns and designs are much imitated by Malaysia, China and Vietnam, although Indonesian batik has been designated as an Indonesian cultural heritage by UNESCO , but this copyright issue must get special attention from the government. Among the various problems above, this creative industry based on Pekalongan batik culture still has the strength and opportunity that has the potential to be an industry with the potential for its development. The strengths of the Pekalongan Batik-based creative industry include: [1] This industry is supported by Pekalongan people and Pekalongan City Government to continue to be developed as an inseparable part of the culture. Batik products are recognized by some as textile products that have high artistic value and are in great demand by the people of Indonesia, even abroad, Batik Pekalongan has its own characteristics and has been recognized worldwide through the UNESCO UNESCO as an Indonesian cultural heritage, while the opportunity to develop Pekalongan Batik is very large because the interest of the people towards batik products is still very high, and still has the opportunity to carry out diversification such as wood batik and printing batik, Batik was made the official fashion that was quite favored by various groups both young and old because of the development of modern designs, motifs, and patterns so that the market side was promising in terms of population Indonesia is quite large. [3] This is similar to Nurainun, Heriyana and Rasyimah stating that the strength and opportunities of the Pekalongan batik industry are that the Pekalongan batik industry is supported by the community to continue to develop the batik industry as an inseparable part of culture because batik products have value high art, certain philosophical and spiritual values and favored by all circles.

Based on the results of research and findings in the field, the direction of the development of a creative industry based on Batik Pekalongan is from the aspect of promotion, infrastructure aspects, and institutional aspects. From the promotion aspect, the development of a creative industry based on Pekalongan batik is aimed at creating a branding strategy for Pekalongan batik through the imaging of Pekalongan batik brands with good quality and maintained and unique Pekalongan so that prices are offered in proportion to their quality, creative design innovations and market developments, even create a trend, Creation of a positive image of Pekalongan Batik through publicity that builds a branding, and helps a product better known to the public, through: radio, social media, television, print media, exhibitions / performances, batik coverage and even facilitation of Pekalongan Batik museum as a publication space public to create Pekalongan Batik brand as high-quality batik and has an artistic value of Indonesian cultural heritage and philosophical values. Branding Strategy is an activity that determines an image that wants to be formed through promotional activities (advertising, publicity and so on). In terms of infrastructure, the Pekalongan Government is committed to building Pekalongan batik city to realize Pekalongan, an advanced city of Mandiri and Prosperous Batik, the Regional Government of Pekalongan City has built landmarks in the form of "BATIK" in front of the Pekalongan Batik Museum. This landmark 
attracts the attention of Pekalongan residents and tourists visiting Pekalongan City. Indirectly, this landmark is also a means to attract visitors to the Batik Museum which is located directly opposite the landmark. through Batik economic development, besides that with a facilitation of Kampung Batik infrastructure and Batik Museum to help access to marketing for industries and batik artisans. The development of the batik village which is the center of Pekalongan batik craft must be facilitated with supporting infrastructure, such as facilitation of batik cloth and batik clothing businesses supported by supporting businesses such as the business of making canting, dyeing clothes and showrooms for showrooms and batik learning for tourists and the public who want to learn batik. For now, the showroom is only used as limited as certain events, therefore showroom facilitation should open opportunities for batik industry participants to show batik works at any time so that they are expected to support the marketing of batik. [4] This is in line with Maya Damayanti and Latifah [4] that the City Government is committed to making Pekalongan a world batik city through the construction of landmarks and structuring of Batik Village and Batik Museum with modern and adequate facilities. Besides the facilitation of modern technologies such as the internet and its infrastructure, telecommunication networks, modern batik making machines need to be presented in the context of business development. Craftsmen can use the internet network to find design inspiration that is a trend, besides that the internet can be used for digital batik making applications. Social media as a means of marketing and transactions of batik industry players can take advantage of internet facilities that are connected to customers/markets. In addition to the opening of outlets and e-commerce services for e-commerce, advertising and publicity by utilizing the internet. The internet network can also be used as a forum for communication between industry players, governments and relevant institutions (universities, banking, etc.) to exchange experiences and information. [5] This is similar to what was stated by Tammanudin who said that the Batik Industry Promotion Pekalongan must be supported by Internet-based technology to create broader marketing communications. From the Institutional aspect, the development of the Pekalongan Batik-based creative industry is directed towards the development of human resources, management/business management development, patent rights for Batik craftsmen who must be supported and facilitated by the Government and authorized IPR institutions and the development of partnerships between industry players and parties interested parties, such as: government, universities, banks, business associations to further empower industry players, especially small-scale creative industries so that positive synergies between industry players, the government and universities are expected to play an active role in the development of Pekalongan batik industry.

\section{Conclusion}

The development of a creative industry based on Batik Pekalongan has great potential because it is supported by abundant cultural wealth, although in its development there are a number of obstacles such as availability of productive, innovative and creative resources, especially human resources which are few masters of good batik techniques, High production costs, unavailability of $\mathrm{R} \& \mathrm{D}$ institutions that help innovation so that designs and batik products tend to be monotonous and less innovative.

The biggest challenges of the creative industry Based on Culture Pekalongan Batik are technological challenges and patent rights. Development direction of Creative Industries based on Pekalongan Batik culture is the development of aspects of promotion, aspects of Infrastructure and Institutional Aspects. 


\section{References}

[1] Fadillah. N. I., "Strategi Dinas Perindustrian Dan Perdagangan Koperasi dan UMKM dalam Pengembangan Industri Kreatif Batik Pekalongan,” J. Adinegara, vol. 5, no. 8, 2016.

[2] A. S. Hidayat and E. Nurdiana, "Strategi Pengembangan SDM Kreatif dalam Menghadapi Masyarakat Ekonomi ASEAN Pada tahun 2016," in Proceedings of the Indocompac, 2016.

[3] Nurainum, Heryana, and Rasymah, "Analisis Industri Batik di Indonesia," J. Fokus Ekon., vol. 7, no. 3, pp. 124-135, 2008.

[4] M. Damayanti and Latifah, "Strategi Kota pekalongan Dalam Pengembangan Wisata kreatif Berbass Industri Batik,” J. Pengemb. Kota, vol. 3, no. 2, pp. 100-111, 2017.

[5] T. Tamamudin, "Promosi Industri Batik Pekalongan (Penerapan, Kemudahan dan Hambatan)," J. Huk. Islam, vol. 13, no. 2, p. 99, Dec. 2015. 